\title{
Design Framework Based on TEC21 Educational Model and Education 4.0 Implemented in a Capstone Project: A Case Study of an Electric Vehicle Suspension System
}

\author{
Hugo A López ${ }^{1}$, Pedro Ponce ${ }^{1}$ (D) Arturo Molina ${ }^{1}$ (D), María Soledad Ramírez-Montoya ${ }^{2}$ and Edgar Lopez-Caudana ${ }^{1, * \mathbb{D}}$ \\ 1 School of Engineering and Sciences, Tecnologico de Monterrey, CDMX 14380, Mexico; \\ a01337462@itesm.mx (H.A.L.); pedro.ponce@tec.mx (P.P.); armolina@tec.mx (A.M.) \\ 2 School of Humanities and Education, Tecnologico de Monterrey, Monterrey 64849, Mexico; solramirez@tec.mx \\ * Correspondence: edlopez@tec.mx
}

\section{check for}

updates

Citation: López, H.A.; Ponce, P.; Molina, A.; Ramírez-Montoya, M.S.; Lopez-Caudana, E. Design

Framework Based on TEC21

Educational Model and Education 4.0 Implemented in a Capstone Project: A Case Study of an Electric Vehicle Suspension System. Sustainability 2021, 13, 5768. https://doi.org/ $10.3390 /$ su13115768

Academic Editor: Jordi Colomer Feliu

Received: 17 March 2021

Accepted: 7 May 2021

Published: 21 May 2021

Publisher's Note: MDPI stays neutral with regard to jurisdictional claims in published maps and institutional affiliations.

Copyright: (c) 2021 by the authors. Licensee MDPI, Basel, Switzerland. This article is an open access article distributed under the terms and conditions of the Creative Commons Attribution (CC BY) license (https:/ / creativecommons.org/licenses/by/ $4.0 /)$.

\begin{abstract}
Nowadays, engineering students have to improve specific competencies to tackle the challenges of 21st-century-industry, referred to as Industry 4.0. Hence, this article describes the integration and implementation of Education 4.0 strategies with the new educational model of our university to respond to the needs of Industry 4.0 and society. The TEC21 Educational Model implemented at Tecnologico de Monterrey in Mexico aims to develop disciplinary and transversal competencies for creative and strategic problem-solving of present and future challenges. Education 4.0, as opposed to traditional education, seeks to provide solutions to these challenges through innovative pedagogies supported by emerging technologies. This article presents a case study of a Capstone project developed with undergraduate engineering students. The proposed structure integrates the TEC21 model and Education 4.0 through new strategies and laboratories, all linked to industry. The results of a multidisciplinary project focused on an electric vehicle racing team are presented, composed of Education 4.0 elements and competencies development in leadership, innovation, and entrepreneurship. The project was a collaboration between academia and the productive sector. The results verified the students' success in acquiring the necessary competencies and skills to become technological leaders in today's modern industry. One of the main contributions shown is a suitable education framework for bringing together the characteristics established by Education 4.0 and achieved by our educational experience based on Education 4.0.
\end{abstract}

Keywords: Education 4.0; Industry 4.0; educational innovation; higher education; skills; competencies; TEC21 Educational Model; electric automotive team

\section{Introduction}

The training of professionals in higher education institutions faces complex challenges in teaching scientific and technological advances and the requirements of creating new solutions to real problems of society. This training is also subject to the need to connect the academic sectors with the governmental, industrial, and social sectors. Changes in educational processes, associated with industry, have also been found along the way, ranging from education (1.0), around the industrial revolution of the 18th century, where the teacher was the center of education because he was in charge of determining and disseminating the essential information needed by students, to processes (2.0) with the imprint of educational technologies, with the first electronic devices used in education, such as printers, calculators and computers, to an education (3.0), within the framework of the third industrial revolution at the end of the 20th century, where automation and the use of resources such as multimedia, virtual tools and laboratories were enhanced, to an education (4.0), which is framed in the fourth industrial revolution, with processes are accompanied by pedagogical technologies and procedures and procedures, and the role of the teacher is that of mentor, referent and collaborator in relation to digital transformations 
and virtualization processes [1]. Because of this, several universities are changing their processes and models to respond to these requirements.

This article presents the case of a Mexican multicampus institution that has radically modified its educational model to focus on training students in disciplinary and transversal competencies. The focus is on describing the integration of this work's Education 4.0 strategies with the new educational model of our university to respond to the needs of Industry 4.0. The article begins with a theoretical framework related to Education 4.0 in the framework of university education, then presents a contextual framework of the TEC21 educational model where the case of this article is integrated. The instrumental case method is presented through a project called escudería due to the worked-on characteristics. The "CCM Borregos Team" on the Tecnologico de Monterrey, campus in Mexico City, collaborates in a new multidisciplinary project. This team participates in the national "Electraton" competition to design an electric vehicle that satisfies established regulations. Currently, the team has shown a loss of interest in improving or innovating, which results in failures in the championship, thus, collapsing the commercial relations with the sponsors. The results are presented and discussed in light of the TEC21 model and the characteristics of Education 4.0. Finally, the conclusions report with characteristics established by Education 4.0 and achieved by our educational experience.

\subsection{Conceptual Framework of Education 4.0 in University Education}

The evolution of education begins with Education 1.0, in which the knowledge is transferred from teacher to students directly. Education 2.0 is a connection between society's needs, so the required knowledge is integrated into the courses. However, creativity is not included. Education 3.0 integrates technological components, so the interactive learning methodology is stimulated. This innovation era promotes exceptional features of parallelism, connectivism, and visualization [2]. On the other hand, Education 4.0 is based on some trends [3]:

- The learning process has to offer in anyplace and anytime.

- The education has to be tailored according to the students' needs and preferences.

- Students decide the best method for learning.

- The students have to be involved in short and long term projects.

- Hands-on learning is a fundament element in the learning experience.

- Making decisions and using logical interpretation using the acquired knowledge is essential.

- Self-learning is mandatory during application projects.

- Achievement of competencies by its graduates.

- Innovation in current learning tools.

- Use of the digital tools and emerging ICTs.

- Projects in living laboratories to produce real learning scenarios.

In the formation of university education, within the framework of Education 4.0, it is relevant to link students with real problems and developed competencies that encourage problem-solving. Reference [4] defined Education 4.0 as the current period in which higher education institutions apply new learning methods, innovative didactic and management tools, and intelligent and sustainable infrastructures complemented by emerging technologies that improve knowledge generation and information transfer processes. Reference [5] postulate for a 4.0 education based on the concept of learning by doing. Students are encouraged to learn and discover different things in a singular way from experimentation. Among the skills most in demand by new learners (and employers) are digital literacy, critical thinking, and problem-solving [6]. In the same sense, reference [7] analyzed the advances and transformations that education has undergone for the formation of digital competencies and how to face the demands of today's society, finding that, in different international and national contexts, they are transforming their technological developments and their academic and labor competitiveness, enhancing the competencies as well as the 
mechanisms of participation of schools and companies, complying with the sustainable development goals.

In Education 4.0, the role of the teacher requires roles aimed at transformation and change. In [8], transactional, transformational, democratic, autocratic, bureaucratic, and charismatic leadership styles positively and significantly affect the teacher's performance. In the era of Education 4.0, this type of teacher's leadership could be a reference for future research in different places [9]. In addition, the teachers could be shown the agents of change and are requested to contribute more to the educational revolution [10]. At present, Education 4.0 has been developed and implemented. Thus, the profile of professor 4.0 was described [11] as a specialized professional with competencies for innovation, complex problem solving, entrepreneurship, collaboration, international perspective, leadership, and connection with the needs of society. Also, reference [12] indicates that academics should support new learning and ideas, formal learning, and external/interface learning.

The use of technology in training environments can be a positive driver or an area of opportunity to promote practices within the framework of Education 4.0. [13] mentioned that barriers continue to prevent wider adoption of Education 4.0 learning technologies, even though these technologies are available in the mainstream consumer market.

Reference [14] presents a historical moment in which postmodernity enters. It has not been able to adapt to information and communication technologies (ICT), the rapid technological innovation, the changes and trends in the industry, the collaborative economy, or the rise of distance careers. On the other hand, reference [15] provides a review of Education 4.0 across a select range of the UK and international higher education providers, highlighting the importance of personal digital assistants, online and lifelong learning in delivering world-class learning and teaching. Besides, in [16], the education sector has to cope with changes in the global economic landscape, as industries are highly technologydriven, and venturing into unconventional learning modalities is needed to maintain efficient and effective development of emerging and future skill needs, thereby increasing its productivity and innovation rates.

Specifically, in engineering education, it is required to develop transformation and change competencies that lead them to postulate for new solutions in the framework of an Education 4.0. Reference [17] mentions that the emergence of Industry 4.0 has inspired education to transform and change its delivery lens towards Education 4.0. Besides, in [18], the challenges in education and lifelong learning process engineers and the industry are explained to safeguard employability and competitiveness. Also, reference [19] enunciates the demand of Industry 4.0 for creative researchers able to adapt to the changing world and to think innovatively and raises the question of educational technologies used to prepare these specialists. Reference [20] emphasizes that teaching and learning approaches, innovation, and value-added experiences of students through technology are part of the concept of Higher Education 4.0. Reference [21] postulates for new recommender systems that represent an essential aspect of Education 4.0, especially for engineering education that is taking advantage of new technologies; or as the use of innovative platforms such as Teachers' Research Exchange in the era of digital transformation and the emerging context of Education 4.0 [22]; as well as bringing open and shared learning platforms, so that schools and teachers can be supported to access, collaborate and undertake research, in the emerging context of Education 4.0 [23].

Likewise, several universities have allocated resources for the design and development of laboratories, whose function is to promote creativity and innovation, the fundamental pillars of "Education 4.0". An example of this is the "Living Laboratory", defined as an active-learning laboratory for activities that resolve real and semi-real problems and challenges [24,25]. Today, the strategy of using living labs and collaborating with industry represents an excellent opportunity for universities to address sustainability challenges while providing students with relevant and real information. In other words, living labs offer a challenging, collaborative, and iterative space for the co-production of knowledge. We could say that this strategy aims to provide a framework for students and teachers 
in an educational environment to apply theoretical knowledge to real-world situations. The generation of living lab projects produces knowledge-enhancing scenarios, without a doubt [26]. Education 4.0 also envisions preparing new professionals who are highly competitive and responsive to current and future needs and challenges. Industry must innovate and promote entrepreneurship to find feasible solutions to the new scenarios' many challenges, many with high social content. Besides, academic institutions and their students must contemplate the challenges and opportunities present in Industry 4.0, such as cloud computing, the Internet of Things, multi-agent systems, cyber-physical systems, and artificial intelligence and their key points [27].

Moreover, industrial trends point to a future with more electric cars, robotics, and artificial intelligence. In Mexico, the lagging of universities in providing graduates with the knowledge, skills, abilities, and technology for this new industry directly relates to the limitations and obsolescence of their current professional curricula. Few have modified their curricula to eliminate or reduce the gap, so the academic communities do not learn the new skills, capacities, and technologies to solve the industry's current and future problems. What is needed is "Education 4.0", which provides new teaching and learning methods using innovative facilities with emerging technologies. Its function is to prepare students to face the future problems of industry [28], seeking to graduate a new generation of highly competitive professionals capable of applying the proper physical and digital resources to provide innovative solutions to current and future societal challenges.

\subsection{The Contextual Framework of the TEC21 Educational Model}

The Tecnologico de Monterrey has been characterized for being at the forefront in terms of educational models and avant-garde when it comes to educational innovations. The new educational model of the Tecnologico de Monterrey is committed to a more practically challenged education, combining theory with the adoption of skills. The rector stated that this new model "will begin in all degree courses and semesters in 2019, although for four years, it is already being implemented partially", today, the current and invigorating model of Tecnologico de Monterrey, has established a panorama of educational vision in Mexico [29]. These connect with Education 4.0, as they offer students attractive projects with challenges that develop new skills, competencies, and knowledge. Tecnologico de Monterrey implemented the "TEC21 Educational Model" on its 26 campuses. It aims to improve its students' competitiveness in different professional fields through comprehensive training and active-learning activities performed collaboratively with partners in the productive sector to develop entrepreneurship, leadership, and innovation competencies. The specific spaces designed for the collaborative and multidisciplinary work among students include the libraries, the Learning Commons, the InnovAction Gym, Labs, and various Active Learning classrooms [30].

Challenge-based learning is the key strategy of the TEC21 model and is transversal in the courses and training instances. The purpose of the courses' challenges is to address industry needs and develop complete product and service solutions, which can be placed and distributed in the industries' solutions portfolios. In this way, the industry can refine the product to an utterly digital-based model proposition. This model must consider the right incentives and find the proper distribution channels. Academic institutions must consider these and many other challenges to train their students. Immersing students in real challenges having the characteristics of Education 4.0 is fundamental in achieving better results [31].

Developing competencies for work and lifelong learning is what is projected in the TEC21 Educational Model. This model has two categories of competencies: disciplinary and transversal (Figure 1 [32]. Disciplinary competencies emphasize the knowledge, attitudes, values, and skills necessary for professional practice; these are required in laboratory procedures in manufacturing, statistical analyses of experiments, and designing software for functional prototypes. Transversal competencies are helpful throughout the life of the graduate in all professional sectors. They directly impact the quality of professional 
practice and include communicating effectively in various situations, showing initiative, creativity, and integrity, and having a good work attitude.

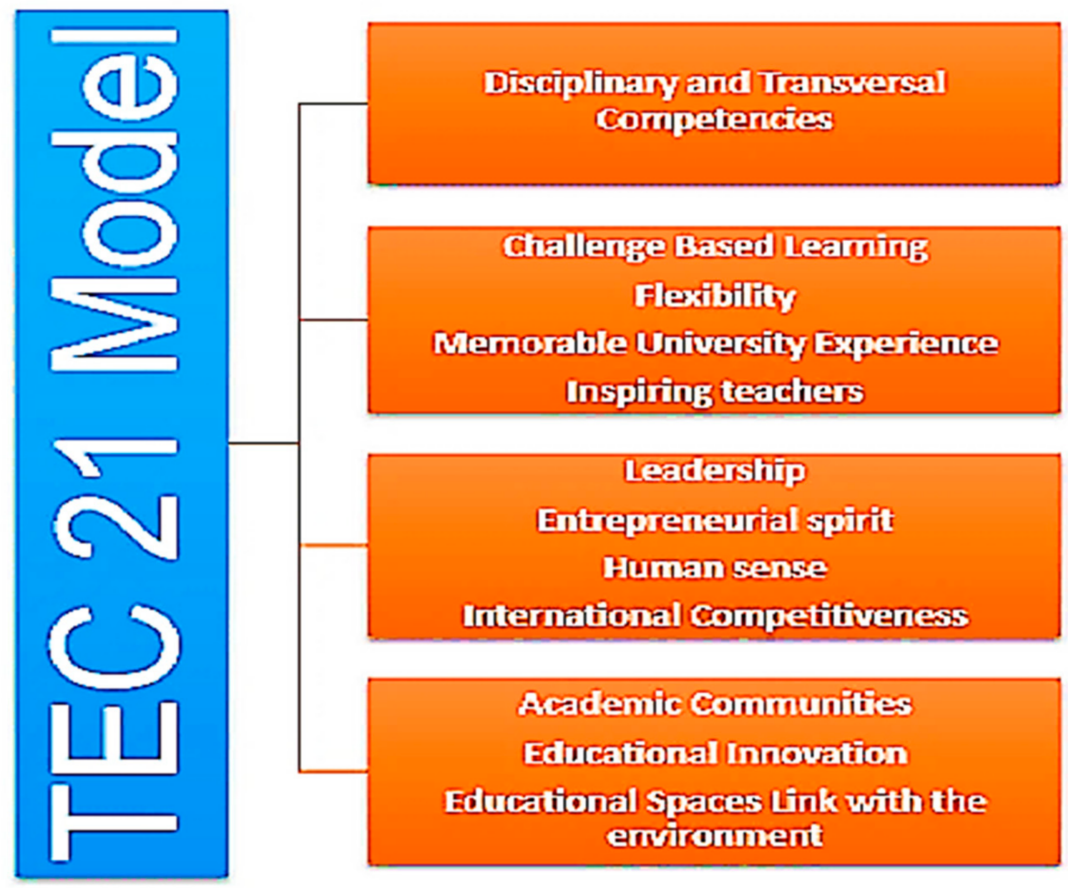

Figure 1. TEC21 Model.

The objective of the undergraduate Mechanical Engineering program at Tecnologico de Monterrey [33] is to prepare professionals competent in the design and innovation of electromechanical systems. They must have skills to select appropriate materials for product manufacturing; select, design, and integrate conventional and advanced manufacturing processes; formulate maintenance schemes; conduct failure analyses; integrate mechanical energy transformation systems; and integrate manufacturing and project management in productive, innovative processes. Throughout their academic programs, students take courses such as Engineering Modeling Using Dynamic Systems, Design of Products Subjected to Static Charges, Design of Mechanisms, or Analysis and Prevention of Faults, which directly address the aspects above. However, this challenge model is where many of the TEC21 objectives converge.

This article outlines the academic and non-academic competencies that are intended to be developed among undergraduate engineering students, presented in an Education 4.0 case study; this exercise illustrates active learning strategies and laboratories designed to collaborate with a company. The case is a multidisciplinary, sustainable project focused on a competitive team designing an electric vehicle suspension system. The project incorporates Education 4.0 elements and competencies. Finally, the results presented show the contributions of innovation and competency formation in undergraduate students.

\section{Methods}

The proposed methodology focuses on an instrumental case study. Instrumental cases are defined by [34] as complex and particular entities, where the situation under study is an instrument to achieve something different from the case itself. The instrumental case study, in this study, is presented with the opportunity to know the results of the development of competencies in undergraduate students through a laboratory where they worked with projects linked to industry.

From its inception, this project was carried out in facilities on the Mexico City Campus of Tecnologico de Monterrey, specifically in the Mechanical Engineering Laboratory, which was transformed into a "Living Laboratory". In this laboratory, the students/members 
could research, create prototypes, validate them, and refine solution proposals for multiple, changing real-life problems [35]. The first stage focused mainly on creating an electric vehicle competitively to obtain the highest mechanical-electrical efficiency and, therefore, excellence during the tests of the national "Electraton" championship. As the project progressed and showed improvements, a channel of trust was to be generated with the current sponsoring companies, fostering the expansion of relations with these companies, with the possibility of their becoming training partners, who would acquire new specialized technologies. The aim is to achieve remarkable improvements by implementing innovations in each area of the project. University teams compete in the only electric car championship in Mexico, where they must manage materials and economic resources and develop academic skills and competencies [36].

This project is exclusively designed and deployed by the students/members of the Mexico City Tecnologico de Monterrey "Borregos" team. The project team is multidisciplinary. In addition to academic engineering disciplines, its range of studies includes academic disciplines such as Economics, Marketing, Industrial Design, and Logistics, which the Industrial Engineer contemplates. Figure 2 illustrates how the team ("Scuderia") project aligns with the TEC21 Educational Model.

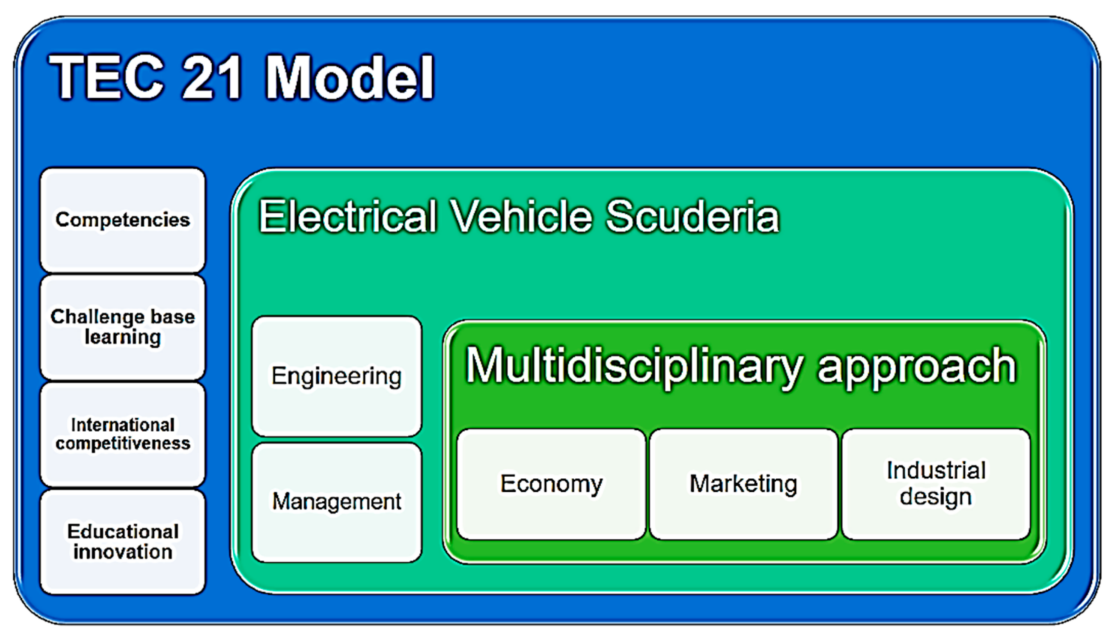

Figure 2. Relationship between the TEC21 Model and the team project.

Figure 3 shows the current organizational chart of the Borregos team organization and the distribution of tasks and responsibilities within the project.

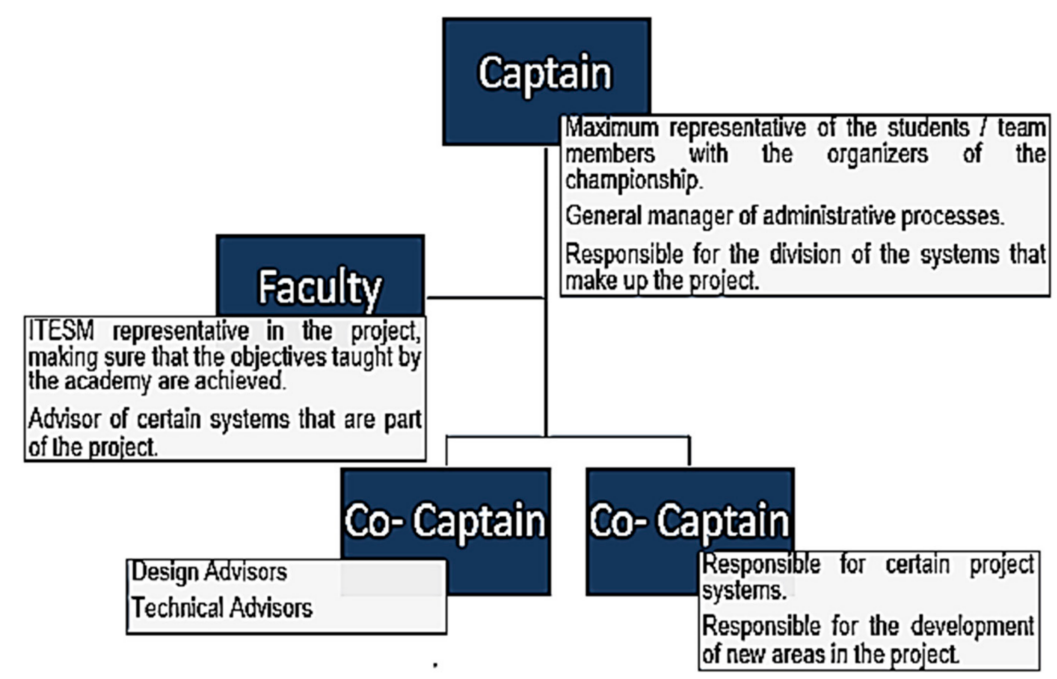

Figure 3. Organization Chart of the "Borregos Team". 
The TEC21 Educational Model uses an adequate schedule for such purposes, considering subjects that last 5, 10, or 15 weeks depending on the semester; some weeks are reserved for developing projects relevant to the student's profile. As students advance in their academic programs, the semesters serve up more challenging projects for practice activities.

However, specific changes in the internal structure of the Borregos Team had to be contemplated to align the established objectives of the new project with the TEC21 Model. Figure 4 shows the new organizational chart for this project. Compared to the first organization, the second distributes the project's system components better under the respective department managers, who collaborated with the teachers and student members. Each system had its financial and technical coordinator to expedite the procedures for purchasing materials and resources by area, avoiding confusion with other departments. The leaders define the main functions and objectives of their departments, which were all interconnected. They specified the first design guidelines and the manufacturing processes, contemplating the members in their custody to obtain a better work distribution. These managers focused on being leaders of their departments' systems, ensuring that each collaborating team member achieved continuous improvement within the project, which entailed having more responsibility. In turn, those in charge of the various systems had to cooperate and communicate to achieve the best possible project performance (see Figure 4).

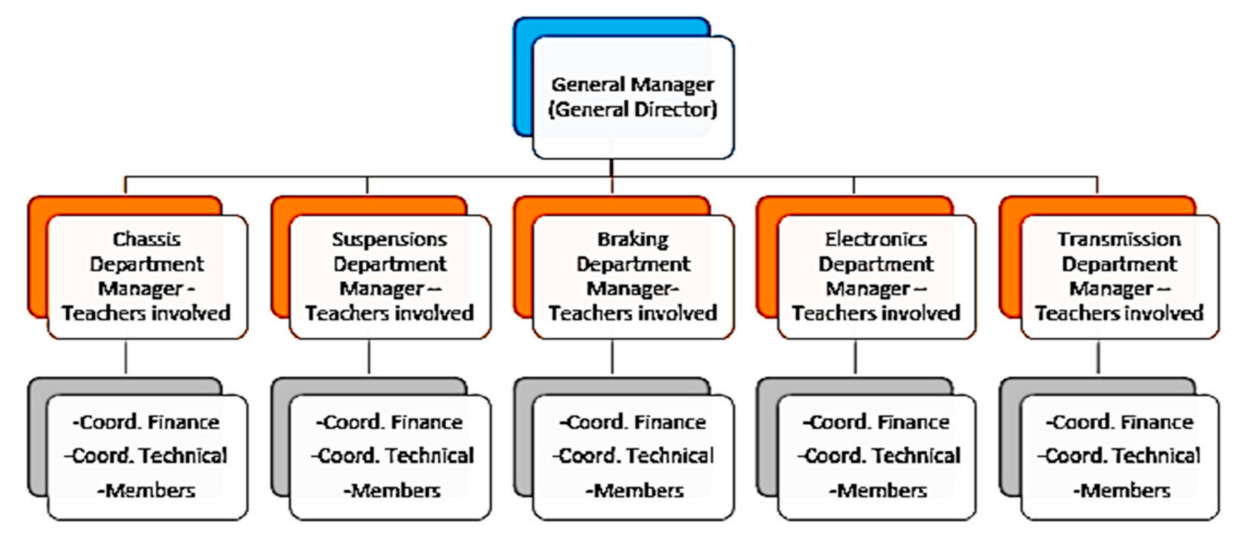

Figure 4. New Organization Chart.

The general project manager responded to the university authorities and the organizers or judges associated with the project competencies. He or she carried out the project's general administration issues and performance reports. The general project managers were the team's formal representatives to the training partners and were required to be in charge of one of the project's systems. This scheme was designed to improve cooperation among team system members and speed up processes that previously had noticeable time delays.

There were design and test engineers and other members from other areas who collaborated to develop a whole system comprised of several elements not limited to engineering disciplines in each project department. In these systems, several modules of the new TEC21 educational model could be applied, including Main Structure (Frame Analysis), Transmission System (Power), Database (test and system design), Electrical System (Sensor, Electric Motor), Suspension System, and Braking System. All of these systems were interdependent. An example of this is presented in Figure 5. 


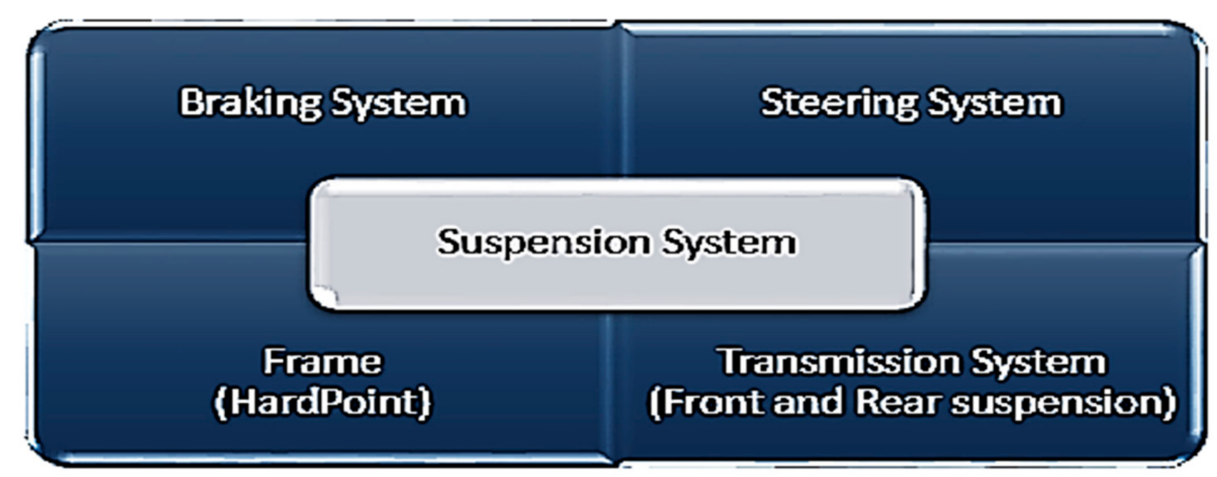

Figure 5. Suspension System.

The suspension system provides better vehicle performance by keeping the tires at the optimum angle to the track through various situations, such as braking, cornering, and accelerating [37]. Tires, shock absorbers, rockers, suspension arms, and uprights comprise the suspension system.

Its relationship with the other systems, as shown in Figure 5, may damage or benefit its behavior depending on the load distribution in the vehicle, the balance of the braking system, the movement caused by a change of direction, and resistance to speed changes by the transmission system. In designing each system, the student/member could implement their theoretical knowledge acquired through the TEC21 learning modules to develop new skills and technical expertise in each vehicle system.

\section{Results}

Suspension System of an "Electraton" and "Formula SAE" Competition

As background related to the case study, there are precedents of a Tec university project on the Mexico City campus where research and tests were carried out in laboratories with physical prototypes. The objective was to improve the performance of an electric vehicle's front suspension system. The traditional suspension system is a set of passive elements intended to minimize road disturbances and improve the vehicle's dynamic performances. It must be designed for the suspension to react optimally during driving, affecting the vehicle's center-of-mass movement as little as possible [37].

Various design techniques can be implemented to minimize the dynamic effects that the vehicle may suffer. Several of these techniques can be found in the literature, but the methods' verification is only theoretical. First, we take the example of the design of a suspension for the "Electraton" competition. In this championship contest, the suspension is of the utmost importance when developing the electric vehicle because of its dimensions. The regulations stipulate two limits for total length and width [38]. Figure 6 shows the minimum dimensions.
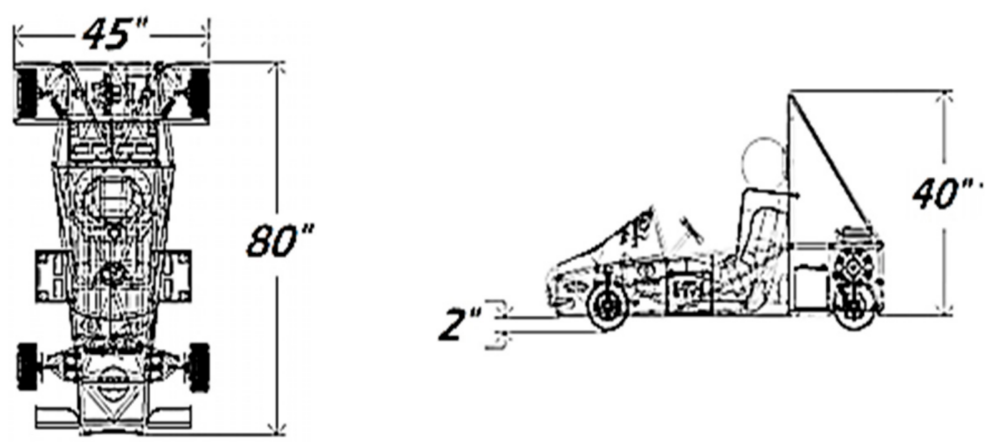

Figure 6. Minimum Dimensions of the "Electraton". 
Similarly, the regulations have a section that mentions that the suspension system should be independent, contemplating a McPherson-type or double wishbone design (see Figure 7).
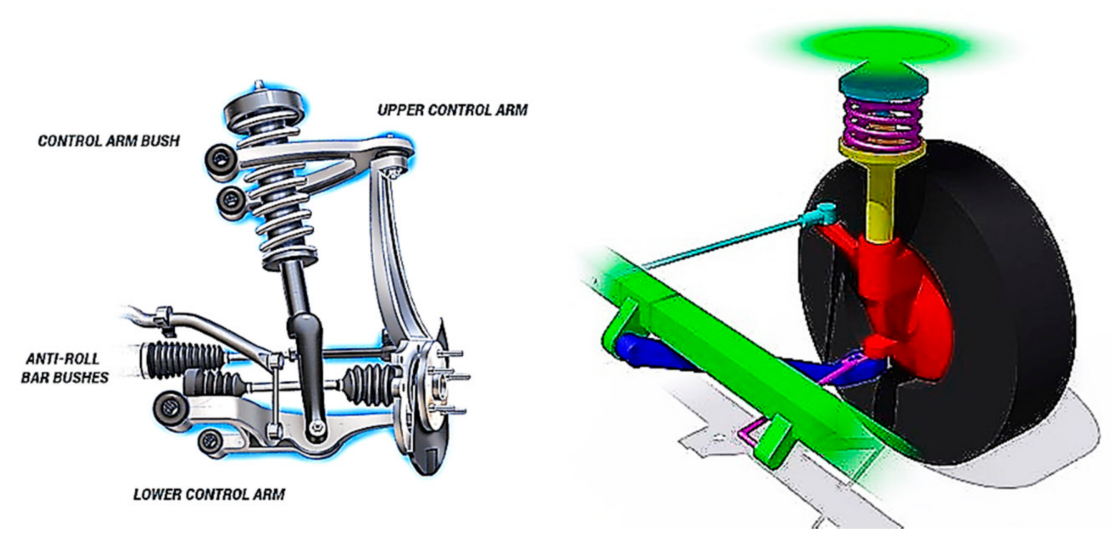

Figure 7. MacPherson and Doble Wishbone Suspensions, adapted from [39,40].

In either case, it must include a spring and shock absorber having a direct connection to the car's main structure. The suspension system should provide an optimum height of at least 2" $(50.8 \mathrm{~mm})$ from the ground in both front and rear suspension systems [38]. Knowing the stipulated measures and components, we proceeded to design such a system; the main goal was to establish the center of mass. It enabled us to know the static loads that the vehicle would have and, consequently, the efforts required to generate the suspension. The equations used to establish the center of mass:

$$
\mathrm{M}_{\mathrm{m}}=\Sigma(\mathrm{m} 1+\mathrm{m} 2+\ldots .+\mathrm{mn})
$$

This equation shows us the sum of the different masses that are part of the vehicle.

We can also establish the distribution of each mass or component within a specific limit previously set by the regulations. We determined the longitudinal and height distribution of the vehicle with the following equations:

$$
\begin{aligned}
\mathrm{l}_{\mathrm{m}} & =\frac{\Sigma(\mathrm{m} 1 \cdot 11+\mathrm{m} 2 \cdot 12+\ldots \ldots+\mathrm{mn} \cdot \mathrm{ln})}{\mathrm{Mm}} \\
\mathrm{h}_{\mathrm{m}} & =\frac{\Sigma(\mathrm{m} 1 \cdot \mathrm{h} 1+\mathrm{m} 2 \cdot \mathrm{h} 2+\ldots \ldots+\mathrm{mn} \cdot \mathrm{hn})}{\mathrm{Mm}}
\end{aligned}
$$

Equations (2) and (3) represent the longitudinal position and the resulting height of the center of mass (see Figure 8).
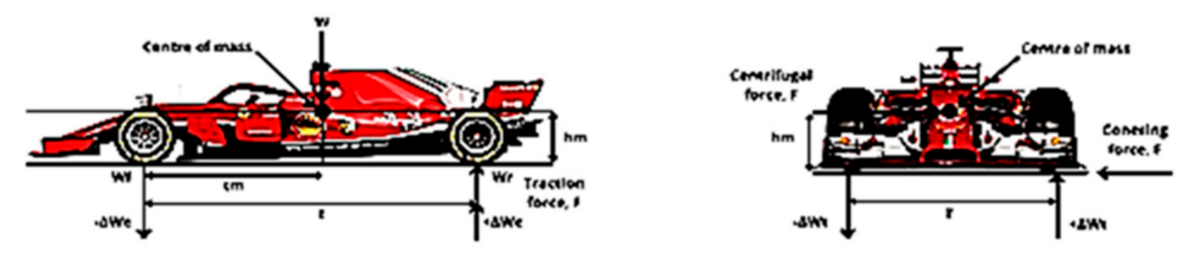

Figure 8. Mass distribution throughout the vehicle, adapted from [37].

By obtaining the total weight and estimating each component's position in the vehicle, we could find the center of mass's distance and height. This allowed us to define the vehicle's weight distribution percentages, obtaining Wf and Wr, representing the weights in the front and rear sections.

The total mass of the vehicle of $225 \mathrm{~kg}$, multiplied by the gravity constant " $\mathrm{g}$ " $\left(9.81 \mathrm{~m} / \mathrm{s}^{2}\right)$, the total vehicle weight $(\mathrm{W})$ is $2207.25 \mathrm{~N}$. 
With these weights defined, we could proceed to find a more suitable wheelbase (L) (the length of the front axle to the rear axle) to allow an optimal distribution of weight for the vehicle through the equation:

$$
\mathrm{W}_{\mathrm{r}}=\mathrm{W} \cdot\left(\frac{\mathrm{lm}}{\mathrm{L}}\right)
$$

The wheelbase (L) obtained was $1353.14815 \mathrm{~mm}$.

Table 1 shows the total of the measurements made, while center of mass and vehicle weight distribution are showed on Tables 2 and 3, respectively.

Table 1. Final Distribution.

\begin{tabular}{|c|c|c|c|}
\hline Item & Mass (Kg) & Horiz. Distance from $x(\mathrm{~mm})$ & Vert. Distance, Ground (mm) \\
\hline Front-wheel assembly & 25 & 0 & 203.2 \\
\hline Pedal box & 5 & 0 & 152.4 \\
\hline Steering gear & 5 & 75 & 120 \\
\hline Engine & 32 & 1150 & 250 \\
\hline Pilot & 70 & 800 & 280 \\
\hline Controls & 3 & 200 & 200 \\
\hline Battery & 5 & 920 & 152.4 \\
\hline Body & 15 & 870 & 260 \\
\hline Structural weight & 0 & 0 & 0 \\
\hline Fuel tank & 25 & 1020 & 200 \\
\hline Exhauts & 5 & 1250 & 160 \\
\hline Drive shaft + Differential & 25 & 1350 & 203.2 \\
\hline Front wing & 5 & -300 & 90 \\
\hline \multirow[t]{2}{*}{ Rear wing } & 5 & 1450 & 350 \\
\hline & 225 & TOTAL & \\
\hline
\end{tabular}

Table 2. Center of Mass Position.

\begin{tabular}{ccc}
\hline Combined Mass $(\mathbf{M m})$ & 225 & Kg \\
\hline Horizontal distance $(\mathrm{lm})$ & 811.8888889 & $\mathrm{~mm}$ \\
\hline Vertical distance $(\mathrm{hm})$ & 232.817778 & $\mathrm{~mm}$ \\
\hline
\end{tabular}

Table 3. Front and rear vehicle weight distribution.

\begin{tabular}{ccc}
\hline Wf & 882.9 & $\mathrm{~N}$ \\
\hline $\mathrm{Wr}$ & 1324.35 & $\mathrm{~N}$ \\
\hline
\end{tabular}

These parameters allowed us to determine the load transfer of the vehicle during a race. In this case, we used an extreme situation for the front suspension during a hard cornering braking. Figure 9 synthesizes this idea. 

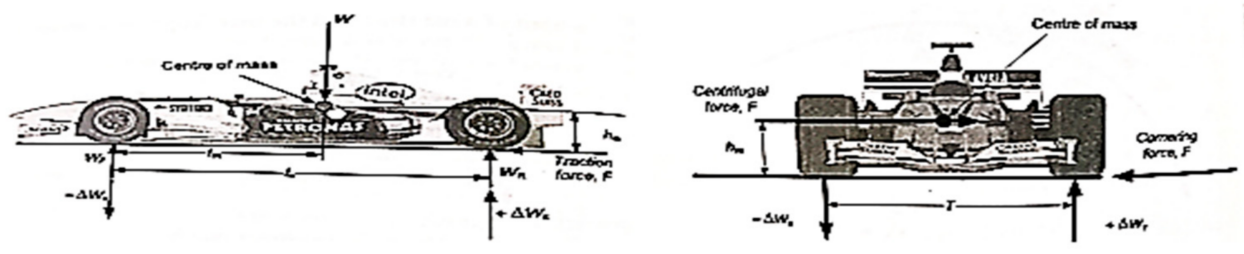

Figure 9. Longitudinal load transfer and lateral load transfer [37].

Tables 4-6, show main aspects of braking and load transfer for vehicle.

Table 4. Braking and longitudinal load transfer.

\begin{tabular}{ccc}
\hline W (Vehicle weight) & 2207.25 & $\mathrm{~N}$ \\
\hline Wr (Rear static load) & 1324.35 & $\mathrm{~N}$ \\
\hline Wf (Front static load) & 882.9 & $\mathrm{~N}$ \\
\hline$\mu$ (Coefficient of friction) & 1.5 & \\
\hline Braking force, FB & 3310.875 & $\mathrm{~N}$ \\
\hline
\end{tabular}

Table 5. Longitudinal weight transfer in braking.

\begin{tabular}{ccc}
\hline FB & 3310.875 & $\mathrm{~N}$ \\
\hline $\mathrm{hm}$ & 232.8177 & $\mathrm{~mm}$ \\
\hline $\mathrm{L}$ & 1353.6571 & $\mathrm{~mm}$ \\
\hline$\Delta \mathrm{Wx}$ (longitudinal weight transfer) & 569.6571 & $\mathrm{~mm}$ \\
\hline $\mathrm{WF}(\mathrm{FB})$ Front brake load & 1452.55 & $\mathrm{~N}$ \\
\hline $\mathrm{WF}(\mathrm{FB})$ Rear brake load & 754.69 & $\mathrm{~N}$ \\
\hline
\end{tabular}

Table 6. Cornering and total lateral load transfer.

\begin{tabular}{ccc}
\hline W (Vehicle weight) & 2207.25 & $\mathrm{~N}$ \\
\hline$\mu$ (Coefficient of friction) & 1.5 & $\mathrm{~mm}$ \\
\hline $\mathrm{T}$ (Track definition) & 1200 & $\mathrm{~N}$ \\
\hline Fco (Maximum cornering force) & 3310.875 & $\mathrm{~N}$ \\
\hline$\Delta \mathrm{Wy}$ (Total lateral weight transfer) & 642.3588 & \\
\hline
\end{tabular}

These loads were a preamble for static analysis of the components of the suspension system. Still, because a vehicle is a highly dynamic object, new complications arise when the vehicle passes over bumps and curbs. The "shock" loads are transmitted through the suspension to the main structure. The actual magnitude of these loads is difficult to determine. However, the design procedures indicated that applying a dynamic factor of " 3 " directly to the total weight of the vehicle [37], together with the respective aerodynamic coefficients, was more than enough to simulate the vehicle dynamics behavior. We call these new charges "Design Loads". In Tables 7-9, it can see the main aspects of dynamic tests for vehicle. 
Table 7. Dynamic vertical loads.

\begin{tabular}{ccc}
\hline W (Vehicle wight) & 2207.25 & $\mathrm{~N}$ \\
\hline Dynamic factor & 3 & \\
\hline DownForce factor & 0.3 & \\
\hline Security factor & 1.3 & $\mathrm{~N}$ \\
\hline Design vertical load & 7482.578 & \\
\hline
\end{tabular}

Table 8. Dynamic braking force.

\begin{tabular}{ccc}
\hline FB (Dynamic) & 8979.093 & $\mathrm{~N}$ \\
\hline$\Delta \mathrm{Wx}$ (Longitudinal dynamic weight transfer)) & 2544.91 & $\mathrm{~N}$ \\
\hline Front-wheel loads & 4537.941 & $\mathrm{~N}$ \\
\hline Rear-wheel loads & 2944.636 & $\mathrm{~N}$ \\
\hline
\end{tabular}

Table 9. Maximum cornering.

\begin{tabular}{cll}
\hline Design vertical load & 7482.578 & $\mathrm{~N}$ \\
\hline Fcor (Maximum cornering force) & 8979.093 & $\mathrm{~N}$ \\
\hline$\Delta \mathrm{Wy}$ (Lateral dynamic weight transfer) & 1742.077 & $\mathrm{~N}$ \\
\hline
\end{tabular}

These results provided an overview of the vehicle behavior in static and dynamic situations. We could use these data to determine:

- Loads that affect the action of the suspension arms, whether lower or higher.

- Behavior with other related systems.

- Appropriate geometry or corresponding reinforcement for the suspension system, covering variables like camber, caster, instant-center, and roll-center.

- Kinematic analysis for the suspension system mechanism.

- Analysis of deformation in reinforcements corresponding to the suspension arms, theoretically, through simulations (FEM) and practice.

- Properties such as stiffness and the damping coefficient required in the suspension system.

- Motion ratio for push-and-pull-rod mechanisms.

With these design parameters already established, we could draw this system's general schemes to actual scale, creating a complete system visualization (Figure 10).

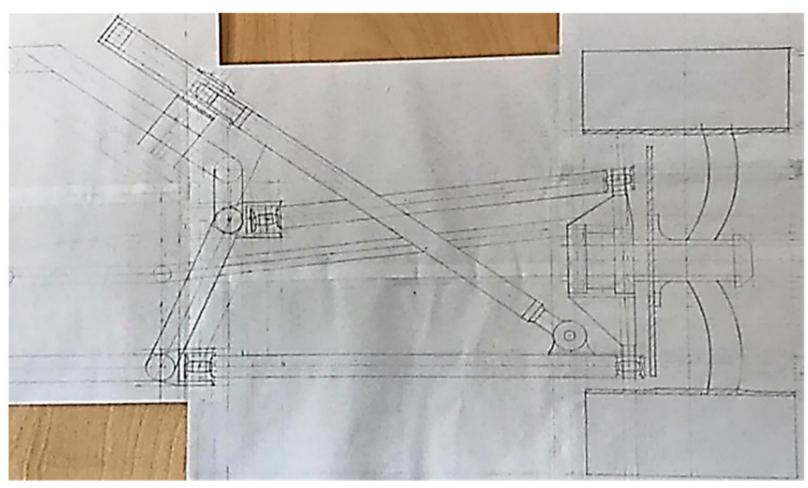

Figure 10. 2D Scheme of Suspension System.

With this scheme presented in 2D complete and not showing visible obstructions or inconsistencies, we could make the system's corresponding CAD drawings. Figures 11-13 illustrate this idea. 

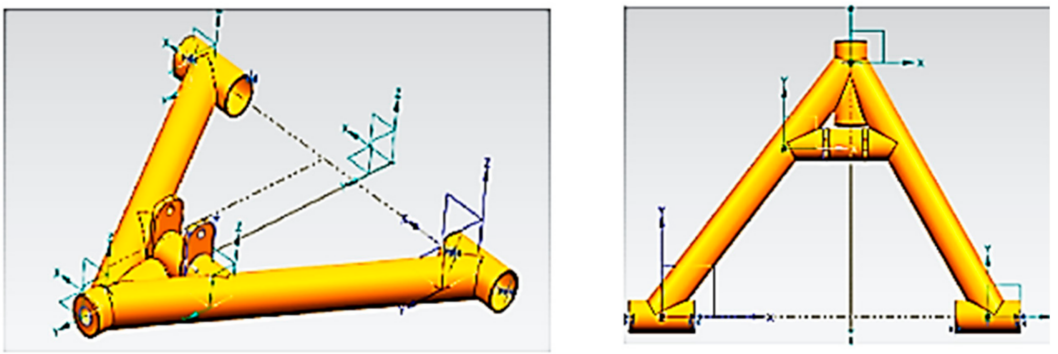

Figure 11. Lower arm suspension CAD.
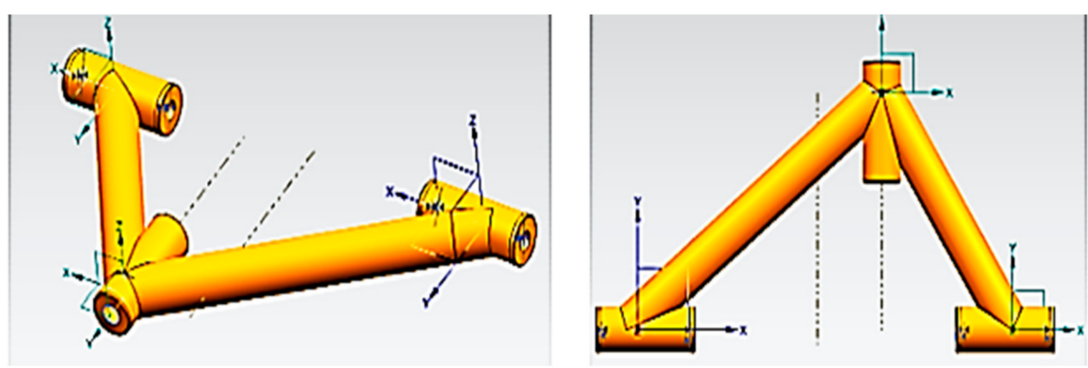

Figure 12. Upper arm suspension CAD.
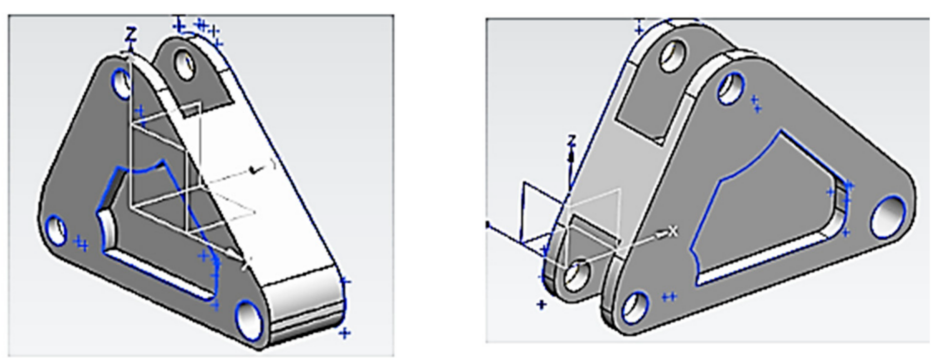

Figure 13. Suspension rocker CAD.

After these CAD drawings, we proceeded to perform a finite element model (FEM) analysis, through which each piece is submitted to its corresponding studies, contemplating its movement restrictions and the load characteristics to which it would be subjected. It is essential to bear in mind that even if these are simulations, they must comply with a specific mandatory safety factor contemplated in the design materials subject to different loads, as shown in Figure 14.
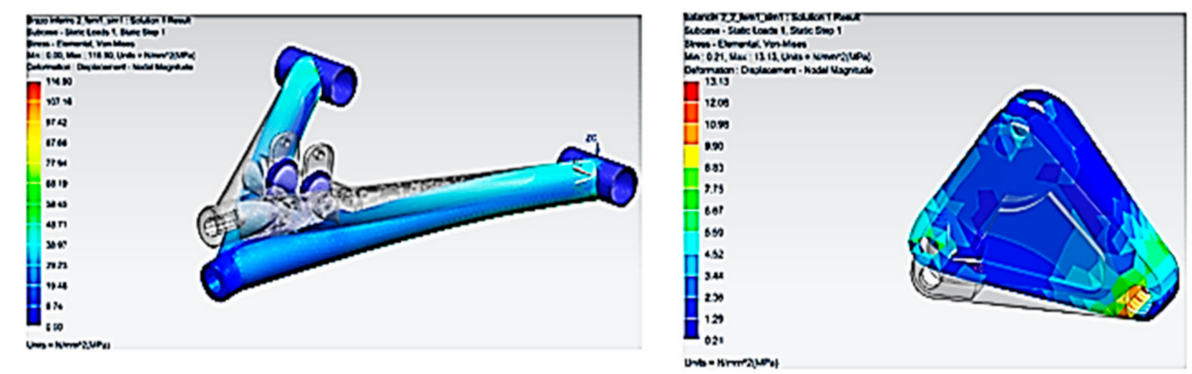

Figure 14. Lower arm and suspension rocker FEM analyses.

Once the FEM simulations and their analyses with the corresponding safety factor were completed, we carried out the vehicle's general assembly to evaluate the calculations previously made (Figure 15). 


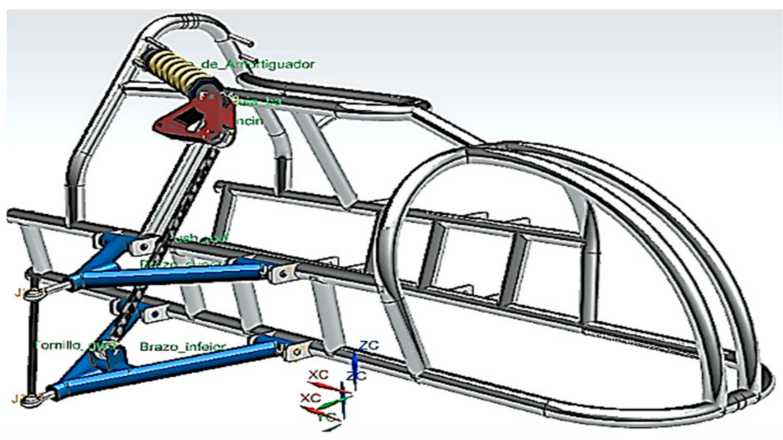

Figure 15. Final assembly CAD.

With the simulations, design, and final assembly already established, each component's prototype machining processes could begin, reviewing compliance with the appropriate tolerances for optimal practical functionality to avoid unnecessary waste of raw material. Figure 16 shows this process.
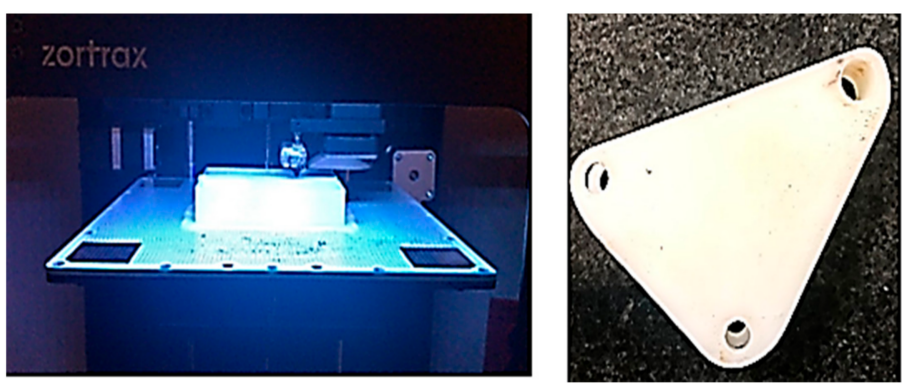

Figure 16. Rocker 3D print process.

The prototype's functionality was satisfactory, so the different processes of the system manufacturing were carried out, such as Manual and CNC lathe, Manual and CNC milling, Welding, and 3D Printing.

Once the physical components are machined, they must be subjected to different resistance tests. For this testing, metric gauges are essential because they provide data on micro deformations at the points where the highest possible stresses can occur (Figures 17 and 18). We could carry out the system's final assembly with the tests satisfactorily performed for each interconnected system. The member (s) involved in this system must follow a series of crucial steps for the assembly, avoiding damaging any other vehicle system. Cooperation among the different vehicle systems teams is critical to obtain the best vehicle behavior during the competition.
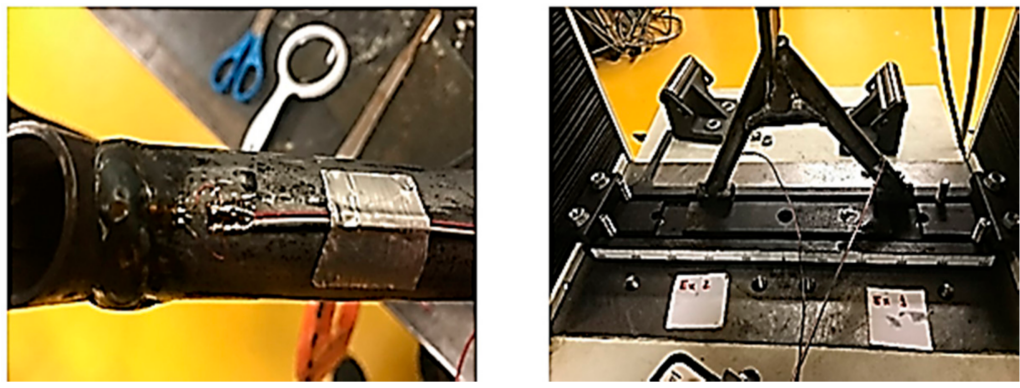

Figure 17. Extensive metric gauges and compression test. 

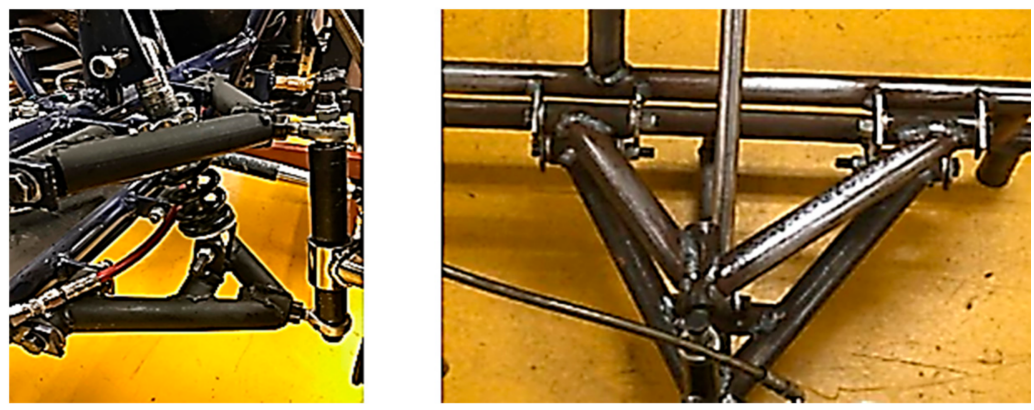

Figure 18. Final assembly.

In this case, the design of the suspension was for a national competition. Still, engineering complexity increases in the opportunity to participate in an international competition, the Formula Student (FSAE). In this competition, there are more restrictions regarding the suspension system, as discussed below:

The technical requirements specified in Article 6 of the general rules of the chassis (T6.1) and the general guidelines for the FSAE suspension system are:

- $\quad$ T6.1.1. The vehicle must be equipped with an operating suspension system, with shock absorbers, front, and rear, having wheel travel of at least $15 \mathrm{~mm}$ to $50.8 \mathrm{~mm}$ during the boat, and bounce with the driver inside the cabin. Judges reserve the right to disqualify cars that do not present a serious attempt at an operational suspension system or demonstrate improper handling for a cross-car circuit [36].

- T6.1.2. All suspension mounting points must be visible on technical inspection, either by direct vision or by removing any cover [36]. Below is a table that shows some of the requirements to consider in the design of a suspension.

With the design parameters mentioned in the previous specifications, it is possible to perform each of the steps mentioned in the case of "Electraton" for the suspension design in this competition, including:

- Theoretical analyses of the center-of-mass, optimal track measurements, and vehicle load distributions.

- Load transfer during different braking, acceleration, and cornering situations.

- The geometry of camber, caster, instant center, and roll center.

- Kinematic analysis of the suspension system.

- Analysis of deformation in reinforcements corresponding to the suspension arms, theoretically, through simulations (FEM) and practice.

- Properties such as stiffness and damping coefficient required in the suspension system.

- Motion ratio for push or pull-rod systems, if used.

With these analyses and operations carried out, it is possible to obtain the components real-scale schematizations. Then, each element is subjected to static and dynamic tests, much stricter than those mentioned previously in the Electraton competition. In the FSAE competition tests, interdisciplinary and disciplinary competencies acquire more value since the vehicle's data and general information are contemplated in engineering and economics, marketing, and administration. The competition judges evaluate verbal and body communication skills, teamwork, and work under pressure. The FSAE Tests include [36]: Static events (Presentation, Cost, and Design) and Dynamic Events (Acceleration, Skid Pad, Autocross, Efficiency, and Endurance).

Once all of the tests on the suspension system components are submitted, the 2D scheme must be performed (Figure 19). 


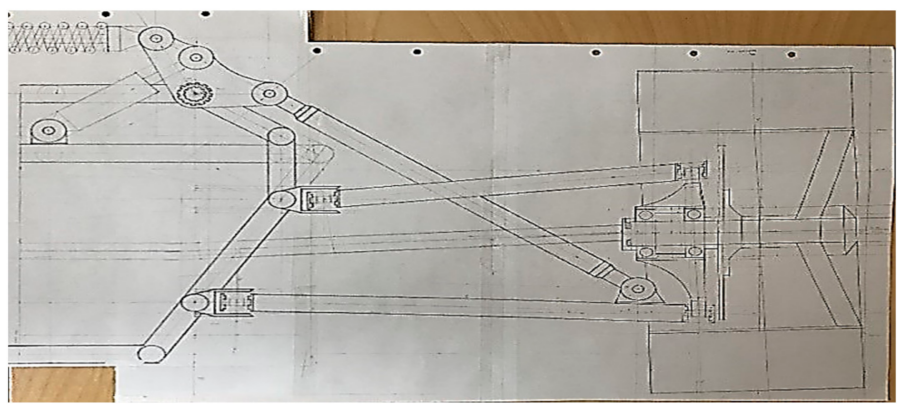

Figure 19. 2D Schematic.

If the scheme does not present problems in assembly, location, and design tolerances, we proceed to 3D modeling (CAD) of the suspension system's components (Figure 20).
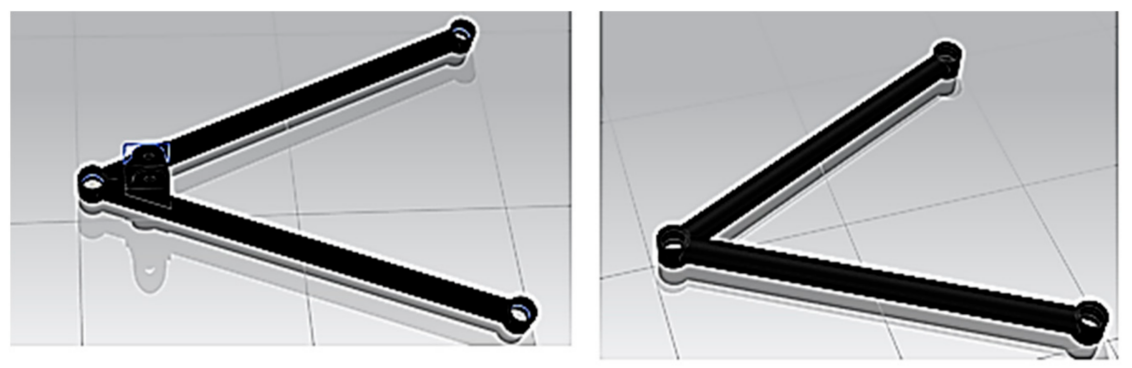

Figure 20. FSAE lower and upper arm.

These models must withstand the movement restrictions, and the characteristics of the loads analyzed using FEM simulations; locating the most significant stress points is possible through these simulations. FEM analysis results are illustrated in Figure 21.

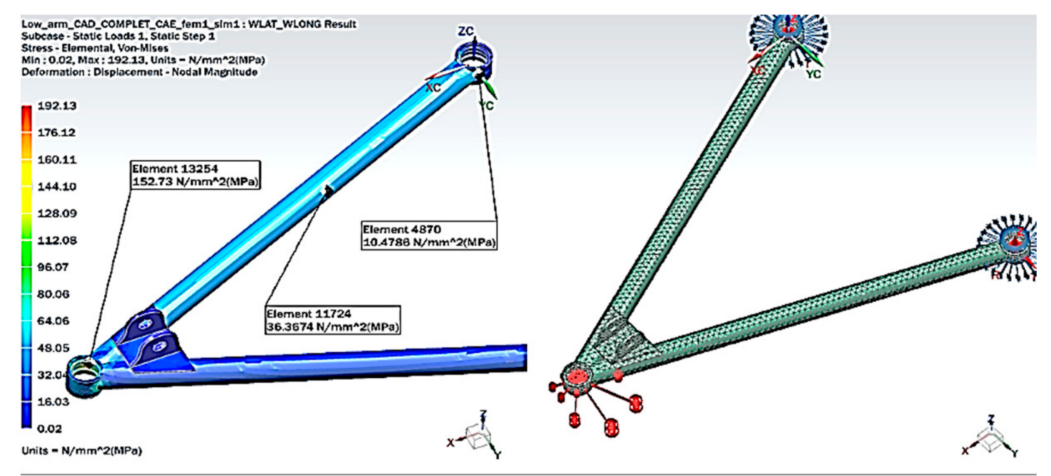

Figure 21. FEM analysis.

With the FEM analyses completed, it is possible to perform the general assembly of the vehicle. Figure 22 shows the final assembly. 

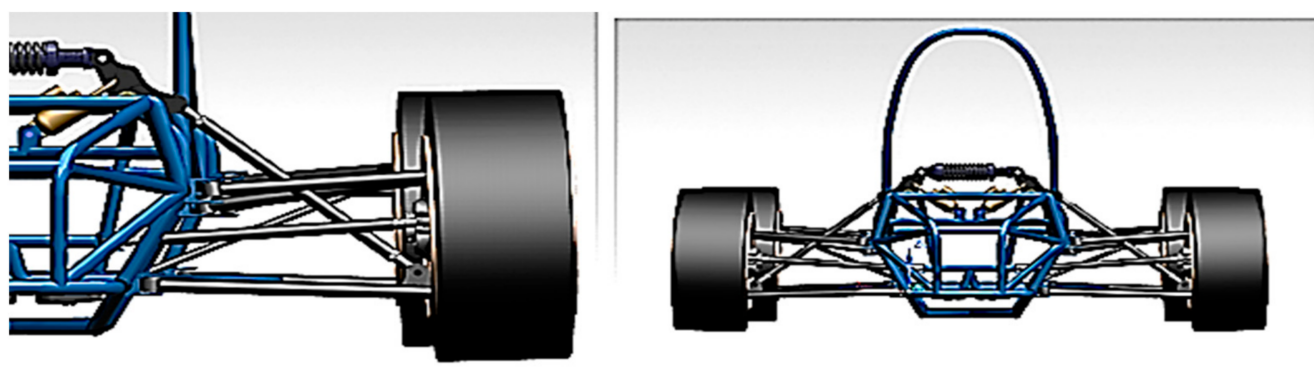

Figure 22. Final CAD assembly.

\section{Discussion}

In the analysis of the case presented, we used direct interpretation from the instrumental case-study perspective. Reference [34] states that direct interpretation is used to locate meanings in the situation with emic themes (essential data for the actors themselves). In his research, reference [41] reported the use of matrices to locate categories of analysis. With these considerations, our research analyses put into perspective the case study of the EV team as an instrument to illustrate the connection of Education 4.0 and the TEC21 Educational Model, as revealed in the study's findings. Table 10 lists the categories connected to the case study.

Table 10. Suspension Solutions, Formal Design Requirements.

\begin{tabular}{cc}
\hline Parameter Description & Requirement of Units \\
\hline Size(Wheelbase) & 62 inch-1.57 $\mathrm{m}$ \\
\hline Production Cost & USD 2000 (Subject to change) \\
\hline Tire Adjustment Capacity & Camber and Track \\
\hline Shock absorber mounting location & Multiple Locations \\
\hline Minimum Chassis Height & 1 inch $/ 25.4 \mathrm{~mm}$ \\
\hline Suspension Movement & No more than 2 inch $-50.8 \mathrm{~mm}$ \\
\hline Security Factor & 1.5 \\
\hline Manufacturing Method & CNC/Welding \\
\hline Assembly Method & Standard Tool
\end{tabular}

\subsection{Relationship_TEC21 Model-Education 4.0-EV Case Study}

Table 11 lists relationships between educative model and developed aspects.

Table 11. Emic topics associated with the TEC21 Model, Education 4.0, and the EV Case Study.

\begin{tabular}{|c|c|c|c|}
\hline TEC21 Educational Model & Education 4.0 & Scudería Case & Emic Topics \\
\hline $\begin{array}{l}\text { Disciplinary competencies } \\
\text { (emphasize the knowledge, } \\
\text { attitudes, values, and skills } \\
\text { necessary for professional } \\
\text { practice) }\end{array}$ & $\begin{array}{l}\text { Competitive professionals } \\
\text { capable of applying innovative } \\
\text { solutions to current and future } \\
\text { societal challenges. } \\
\text { Achievement of exit } \\
\text { competencies in learners. }\end{array}$ & $\begin{array}{l}\text { Static Equilibrium Analysis, Engineering } \\
\text { Modeling-Dynamic Systems, } \\
\text { Fundamentals of Materials Engineering, } \\
\text { Analysis and Prevention of Failures, } \\
\text { Manufacturing Engineering, Control } \\
\text { Systems Engineering }\end{array}$ & $\begin{array}{l}\text { Avant-guard disciplinary } \\
\text { knowledge to train competent } \\
\text { professionals }\end{array}$ \\
\hline $\begin{array}{l}\text { Transversal competencies } \\
\text { (training experiences in } \\
\text { entrepreneurship, leadership, } \\
\text { innovation, linking academia } \\
\text { and the productive sector) }\end{array}$ & $\begin{array}{l}\text { Develop attractive projects for } \\
\text { students through the } \\
\text { implementation of challenges to } \\
\text { develop new skills, } \\
\text { competencies, and knowledge }\end{array}$ & $\begin{array}{l}\text { Analysis and resolution of different } \\
\text { situations that arise in the project use } \\
\text { technologies to adapt and innovate in an } \\
\text { environment of constant change, such as } \\
\text { Industry 4.0. Competencies: } \\
\text { Self-knowledge and management, } \\
\text { reasoning to face complexity, } \\
\text { communication, digital transformation. }\end{array}$ & $\begin{array}{l}\text { Transversal knowledge linked } \\
\text { to problems to train } \\
\text { competent professionals } \\
\text { committed to society }\end{array}$ \\
\hline
\end{tabular}


Table 11. Cont.

\begin{tabular}{|c|c|c|c|}
\hline TEC21 Educational Model & Education 4.0 & Scudería Case & Emic Topics \\
\hline $\begin{array}{l}\text { Challenging experiences } \\
\text { (flexibility, problematic, search } \\
\text { for creative solutions) }\end{array}$ & $\begin{array}{l}\text { New teaching and learning } \\
\text { methods using innovative } \\
\text { facilities with emerging } \\
\text { technologies, whose function is } \\
\text { to prepare students to face the } \\
\text { future problems of the industry }\end{array}$ & $\begin{array}{l}\text { The project team consisted of academic } \\
\text { Engineering disciplines, Economics, } \\
\text { Marketing, Industrial design, Logistics: } \\
\text { branches contemplated by the Industrial } \\
\text { Engineer, obtaining new skills and } \\
\text { technical expertise to develop each system } \\
\text { comprising the vehicle. }\end{array}$ & $\begin{array}{l}\text { Challenging situations to } \\
\text { encourage creativity and new } \\
\text { possibilities }\end{array}$ \\
\hline $\begin{array}{l}\text { Innovative spaces } \\
\text { (multidisciplinary and } \\
\text { collaborative work among } \\
\text { students, using the libraries, the } \\
\text { Learning Commons, the } \\
\text { InnovAction Gym, labs, and } \\
\text { various Active Learning } \\
\text { classrooms). }\end{array}$ & $\begin{array}{l}\text { Innovation in current learning } \\
\text { tools in universities uses current } \\
\text { digital tools or ICTs that have } \\
\text { been generated; real learning } \\
\text { scenarios through projects and } \\
\text { living laboratories developed } \\
\text { for such purposes. }\end{array}$ & $\begin{array}{l}\text { Mechanical Engineering Laboratory, } \\
\text { transformed into a "Living Laboratory", } \\
\text { where students/members can research, } \\
\text { create prototypes, validate them, and } \\
\text { refine solutions in multiple and changing } \\
\text { real-life contexts. }\end{array}$ & $\begin{array}{l}\text { New spaces and emerging } \\
\text { technologies for learning and } \\
\text { creative collaboration. }\end{array}$ \\
\hline $\begin{array}{l}\text { Liaison with the public and } \\
\text { private sectors }\end{array}$ & $\begin{array}{l}\text { A new generation of highly } \\
\text { competitive professionals } \\
\text { capable of applying suitable } \\
\text { physical and digital resources to } \\
\text { propose innovative solutions to } \\
\text { current and future societal } \\
\text { challenges }\end{array}$ & $\begin{array}{l}\text { New solutions and innovations aligned } \\
\text { with the latest industry trends. }\end{array}$ & $\begin{array}{l}\text { Open innovation for } \\
\text { co-creation to impact } \\
\text { government, social, business, } \\
\text { and academic sectors }\end{array}$ \\
\hline
\end{tabular}

\subsection{Relationship_TEC21 Model-Education 4.0-Capstone Project}

As mentioned earlier, the study's specified project conforms to the TEC21 Educational Model. Sometimes, the academic programs' challenges do not arouse students' interest because they only manifest or reflect theoretical knowledge without actual practice or testing. This project's advantage lies in its relating to the different TEC21 learning modules and proposing solutions to the challenges set out in each course. The students acquire knowledge and skills by making functional prototypes subject to constant improvements, simulating the skills and knowledge that the students pursue in search of excellence during their professional careers.

Also, this project presents excellent academic flexibility since one of its advantages is the vast area of opportunity to focus on professional skills and passions according to the interests of the students, in this case, aligning their knowledge acquired in the modules to specific vehicle systems. The students can explore, decide, and specialize during their training process, complementing it with a concentration. Participating in research collaborations with their teachers in each academic area and the project training partners from industry, the students acquire specific tools or certifications in the curriculum beneficial to them as they integrate into working life [32].

The competition judges evaluate verbal and non-verbal communication skills, teamwork, and work under high pressure. The FSAE Tests include [36]: static events that include the presentation of the designed vehicle, the cost required to develop the vehicle, and the design elements. Usually, the team has to look for funding opportunities that help to improve the vehicle's design. However, the low cost of designing the vehicle is encouraged. Hence, creativity for solving design problems is promoted. Dynamic events regarding the dynamic performance of the vehicle are done. Those events include acceleration, skidpad, autocross, efficiency, and endurance.

As a result of this project, some students were connected to companies such as Tesla, in which they did an internship since those companies find in those students the skills and competencies they are searching for. (https://tec.mx/es/noticias/ciudad-de-mexico/ educacion/piden-en-tesla-talento-del-tec, accessed on 5 April 2021) and (https://tec.mx/ es/noticias/ciudad-de-mexico/institucion/abre-tesla-sus-puertas-dos-alumnos-del-tec-ciudadde-mexico, accessed on 5 April 2021). It is essential to mention that those skills and companies allow students to become technological leaders 


\section{Conclusions}

The training of professionals with a creative vision involves placing students in the realm of real problems. This article highlights the formation of students' competencies, supported by an educational model that aims to develop innovation and problem-solving skills, to make them agents of change. The students who worked on their projects developed competencies through theoretical analyses, creative designs, simulations, and acceleration and validation of the team's prototype. The students came up with good transmission designs due to acquiring avant-garde knowledge and concrete competencies linked to real problems. This educational experience can support students in facing new challenges, which is the aim of the TEC21 Educational Model, putting students into practice with different challenges to provide creative solutions. Through constant experimentation and experiential learning, they can scale mastery levels of the model's established competencies.

This case study focused on improving the suspension systems by adequately managing the data presented during specific driving situations, such as braking, cornering, or accelerating. Contemplating the longitudinal mass distribution, the geometry of specific structural components, composite materials, damping systems, and manufacturing processes using research modules, digital technology, and design software improved vehicle performance. The performance of these activities led to the efficient acquisition of skills and competencies in the students involved. The TEC21 Educational Model favored the students' development and involvement in constructing the automotive systems, proving it to be a suitable methodology that could work in similar projects.

Education 4.0 emphasizes problem-solving training, mediated by emerging technologies and innovative strategies. This project developed in the student/members the core elements of the TEC21 Educational Model, such as leadership, innovation, and entrepreneurship. It linked academia with the productive sector; the students inspired and influenced the people in their environment to work together for a common goal. This boosted their entrepreneurial spirit; they passionately proposed and implemented innovative solutions that transformed their reality, identifying the areas of opportunity and analyzing the risks and uncertainties in the project. If necessary, in case of failure, they could proceed to a rapid recovery. This experience ensures that, in the future, these same students will be able to promote the creation of high-impact companies.

This case study only considered the suspension system, which, as already mentioned, depends on other systems. By expanding and monitoring the design processes and acquiring data, as in this case study, there can be a design platform based on training, active learning experiences, and acquired self-knowledge through the TEC21 educational learning modules. With these advances, the communication among various project areas would reinforce research into innovative components or solutions that improve the vehicle performance without putting the other automotive systems at risk. These innovations would be designed, simulated, and manufactured in the laboratory where the project is developed, encouraging cooperation with training partners to create new products using new emerging technologies in the global market. With these innovations, the possibility of participating in international competitions is feasible. Participating in such competitions (competitive or commercial) offers project development and long-term monitoring, which would position Tecnologico de Monterrey, Mexico City Campus, as a center for innovation and use of emerging technologies in sustainable electric motoring.

Future research can be strengthened by a mixed methodology, exploring the previous levels of competency mastery and the final levels quantitatively while also supplementing qualitative analyses that enrich the data. We invite further research studies on educational innovation that provide empirical evidence of new strategies, processes, and products.

\section{Future Development Proposals}

When a multidisciplinary project is carried out, the open innovation laboratory allows joining all the required elements such as universities, industries, and governmental institutions like a unified team. The design structure that provides the open innovation laboratory 
results in a completely open design topology that grasps all the elements together. All of them can be active during the design process and integrates new ideas. As a result, when the students work on designing an electric vehicle under the open innovation laboratory, the vehicle becomes a living lab that makes available new engineering challenges aligned whit Education 4.0 to achieve advanced engineering skills.

This project has several opportunities for innovation and development in different systems in the short, medium, or long terms. The suspension system is covered in the case study; however, there are still components or methods to improve it. Other systems such as the transmission, braking system, fundamental structure, or even electronic improvements can benefit this study. Figure 23 shows several aspects for future scenarios.
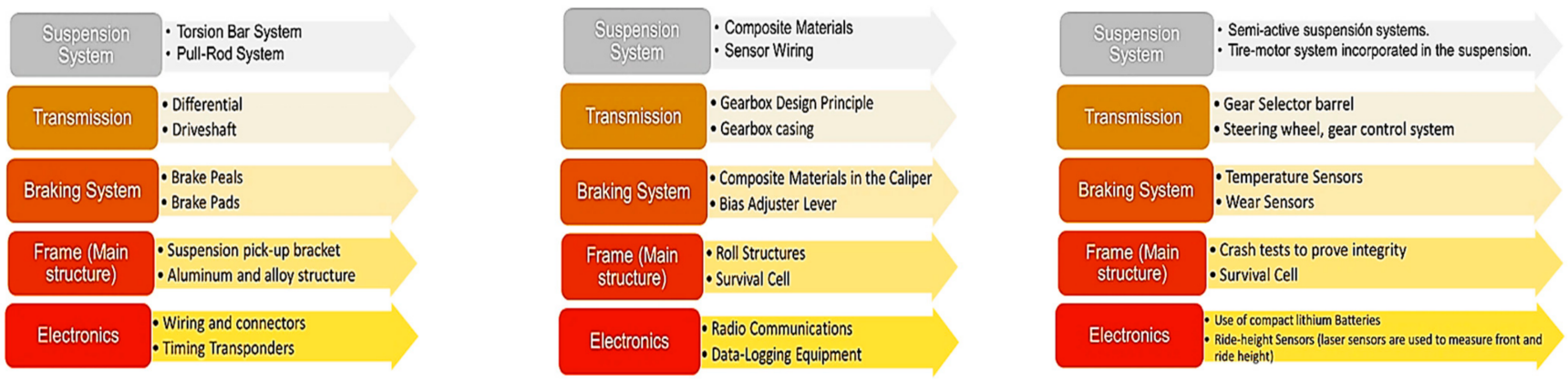

Figure 23. Short, Medium, and Long Term Developments.

Open innovation for these developments is an excellent way to link higher education institutions and industry, which would result in open designs by teams and the development of innovation, leadership, and entrepreneurship skills through co-construction spaces, such as living laboratories. Of substantial importance is to use metrics to measure undergraduates' skills and competencies to contribute to Education 4.0 and Industry 4.0. The goal is to train undergraduates to be professionals committed to innovation and the desire to impact societal well-being using sustainability methodologies.

Author Contributions: Conceptualization, P.P. and A.M.; methodology, P.P., H.A.L. and M.S.R.M.; software, H.A.L.; validation, H.A.L., P.P. and A.M.; formal analysis, E.L.-C. and M.S.R.-M.; investigation, H.A.L.; resources, P.P. and A.M.; data curation, P.P.; writing-original draft preparation, P.P.; writing-review and editing, M.S.R.-M. and E.L.-C.; visualization, E.L.-C.; supervision, P.P.; project administration, P.P.; funding acquisition, A.M. All authors have read and agreed to the published version of the manuscript.

Funding: The authors would like to acknowledge the financial support of Writing Lab, Institute for the Future of Learning, Tecnologico de Monterrey, Mexico, in the production of this work.

Acknowledgments: The authors would like to acknowledge the technical support of Writing Lab, Institute for the Future of Learning, Tecnologico de Monterrey, Mexico, in the production of this work.

Conflicts of Interest: The authors declare no conflict of interest.

\section{References}

1. Miranda, J.; Molina, A. Designing Hybrid Learning Programs in Higher Education by Applying Education 4.0: The Innovation Challenge Bootcamp as Case Study. In Proceedings of the 2020 IEEE Learning With MOOCS (LWMOOCS), Antigua Guatemala, Guatemala, 29 September-2 October 2020; pp. 31-36.

2. Puncreobutr, V. Education 4.0: New challenge of learning. St. Ther. J. Humanit. Soc. Sci. 2016, 2, 92-97.

3. Evans, J.; Jones, R.; Karvonen, A.; Millard, L.; Wendler, J. Living labs and co-production: University campuses as platforms for sustainability science. Curr. Opin. Environ. Sustain. 2015, 16, 1-6. [CrossRef]

4. Miranda, J.; Lopez, C.S.; Navarro, S.; Bustamante, M.R.; Molina, J.M.; Molina, A. Open Innovation Laboratories as Enabling Resources to Reach the Vision of Education 4.0. In Proceedings of the 2019 IEEE International Conference on Engineering, Technology and Innovation (ICE/ITMC), Valbonne Sophia-Antipolis, France, 17-19 June 2019; pp. 1-7.

5. Almeida, F.; Simoes, J. The Role of Serious Games, Gamification and Industry 4.0 Tools in the Education 4.0 Paradigm. Contemp. Educ. Technol. 2019, 10, 120-136. [CrossRef] 
6. Peredrienko, T.; Belkina, O.; Yaroslavova, E. New Language Learning Environment: Employers'-Learners' Expectations and the Role of Teacher 4.0. Int. J. Instr. 2020, 13, 105-118. [CrossRef]

7. Bernate, J.A.; Guativa, J.A.V. Desafíos y tendencias del siglo XXI en la educación superior/ Challenges and trends of the 21st century in higher education. Rev. De Cienc. Soc. 2020, 26, 141-154.

8. Kadiyono, A.L.; Sulistiobudi, R.A.; Haris, I.; Wahab, M.K.A.; Ramdani, I.; Purwanto, A.; Sumartiningsih, S. Develop leadership style model for indonesian teachers performance in Education 4.0 era. Syst. Rev. Pharm. 2020, 363-373. [CrossRef]

9. Indrawan, I.; Evanirosa; Ali, R.; Indra, R.; Hanif, M.; Sumartiningsih, S. Develop model of transactional, transformational, democratic and authocratic leadership style for indonesian school performance in Education 4.0 era. Syst. Rev. Pharm. 2020, 409-419. [CrossRef]

10. Sudaryono; Lutfiani, N.; Suseno; Aini, Q. Empirical study of research performance leading to education 4.0 using the ilearning method. Int. J. Adv. Trends Comp. Sc. Eng. 2019, 8, 264-268.

11. Ramírez-Montoya, M.; Loaiza-Aguirre, M.; Zúñiga-Ojeda, A.; Portuguez-Castro, M. Characterization of the Teaching Profile within the Framework of Education 4.0. Future Internet 2021, 13, 91. [CrossRef]

12. Ishak, R.; Mansor, M. The Relationship between Knowledge Management and Organizational Learning with Academic Staff Readiness for Education 4.0. Eurasian J. Educ. Res. 2020, 20, 169-184. [CrossRef]

13. Adnan, A.H.M.; Shak, M.S.Y.; Karim, R.A.; Tahir, M.H.M.; Shah, D.S.M. 360-Degree Videos, VR Experiences and the Application of Education 4.0 Technologies in Malaysia for Exposure and Immersion. Adv. Sci. Technol. Eng. Syst. J. 2020, 5, 373-381. [CrossRef]

14. Alvarez-Cedillo, J.; Aguilar-Fernandez, M.; Sandoval-Gomez, R.J.; Alvarez-Sanchez, T. Actions to be taken in Mexico towards education 4.0 and society 5.0. Int. J. Eval. Res. Educ. 2019, 8, 693-698.

15. Bonfield, C.A.; Salter, M.; Longmuir, A.; Benson, M.; Adachi, C. Transformation or evolution?: Education 4.0, teaching and learning in the digital age. High. Educ. Pedagog. 2020, 5, 223-246. [CrossRef]

16. Anito, J.C., Jr.; Morales, M.P.E. The Pedagogical Model of Philippine STEAM Education: Drawing Implications for the Reengineering of Philippine STEAM Learning Ecosystem. Univers. J. Educ. Res. 2019, 7, 2662-2669. [CrossRef]

17. Koul, S.; Nayar, B. The holistic learning educational ecosystem: A classroom 4.0 perspective. High. Educ. Q. 2021, 75, 98-112. [CrossRef]

18. Wilk, M.; Rommel, S.; Liauw, M.A.; Schinke, B.; Zanthoff, H. Bildung 4.0: Herausforderungen für die Aus- und Fortbildung. Chem. Ing. Tech. 2020, 92, 983-992. [CrossRef]

19. Volchenkova, K.N. Flipped Classroom for Doctoral Students: Evaluating the Effectivness. Vyss. Obraz. V Ross. High. Educ. Russ. 2019, 28, 94-103. [CrossRef]

20. Goh, P.S.-C.; Abdul-Wahab, N. Paradigms to Drive Higher Education 4.0. Int. J. Learn. Teach. Educ. Res. 2020, 19, 159-171. [CrossRef]

21. Mogoş, R.; Bodea, C. Recommender systems for engineering education. Rev. Roum. Sci. Tech. Ser. Electrotech. Energetique 2019, 64, 435-442.

22. Alakrash, H.; Razak, N.A.; Krish, P. Social network sites in learning english; an invstigation on attitudes, digital literacy and usage. Linguist. Antverp. 2021, 2021, 26-43.

23. Connolly, C.; Hall, T.; Ryan, M.; McMahon, J.; McGann, M.; Egan, A. A fusion of research-informed teaching and teachinginformed research: Designing a scalable online ecosystem for new partnerships in educational research. Australas. J. Educ. Technol. 2020, 37, 82-95. [CrossRef]

24. Puerari, E.; De Koning, J.I.J.C.; Von Wirth, T.; Karré, P.M.; Mulder, I.J.; Loorbach, D.A. Co-Creation Dynamics in Urban Living Labs. Sustainability 2018, 10, 1893. [CrossRef]

25. Voytenko, Y.; McCormick, K.; Evans, J.; Schliwa, G. Urban living labs for sustainability and low carbon cities in Europe: Towards a research agenda. J. Clean. Prod. 2016, 123, 45-54. [CrossRef]

26. Selamat, A.; Alias, R.A.; Hikmi, S.N.; Puteh, M.; Tapsi, S.M. Higher Education 4.0: Current status and readiness in meeting the fourth industrial revolution challenges. Redes. High. Educ. Ind. 2017, 4, $23-24$.

27. Fitsilis, P.; Tsoutsa, P.; Gerogiannis, V. Industry 4.0: Required personnel competencies. Industry 2018, 3, $130-133$.

28. Miranda, J.; Chavarría-Barrientos, D.; Macías, M.; Molina, M.; Ponce, P.; Molina, A.; Wright, P.K. Experiences in interactive collaborative learning using an open innovation laboratory: The design methodologies course as case study. In Proceedings of the 2017 International Conference on Engineering, Technology and Innovation (ICE/ITMC), Madeira, Portugal, 27-29 June 2017; pp. 1235-1242.

29. Tecnológico de Monterrey. Historia del Modelo Educativo del Tec de Monterrey. 2019. Available online: https://tec.mx/es/ nosotros/nuestra-historia (accessed on 26 March 2021).

30. Ponce, P.; Polasko, K.; Molina, A. Open innovation laboratory in electrical energy education based on the knowledge economy. Int. J. Electr. Eng. Educ. 2019, 0020720919829711. [CrossRef]

31. Miranda, J.; Rosas-Fernandez, J.B.; Molina, A. Achieving Innovation and Entrepreneurship by Applying Education 4.0 and Open Innovation. In Proceedings of the 2020 IEEE International Conference on Engineering, Technology and Innovation (ICE/ITMC), Cardiff, UK, 15-17 June 2020; pp. 1-6.

32. Tecnológico de Monterrey. Modelo TEC21. 2019. Available online: https://tec.mx/es/noticias/nacional/educacion/el-tectransforma-su-modelo-educativo-sera-mas-flexible-y-vivencial (accessed on 26 March 2021). 
33. Tecnológico de Monterrey. BSc Mechanical Engineering. 2020. Available online: https://tec.mx/es/innovacion-ytransformacion/ingeniero-mecanico (accessed on 18 February 2021).

34. Stake, R.E. Multiple Case Study Analysis; Guilford Press: New York, NY, USA, 2013.

35. Frantzeskaki, N.; Broto, V.C.; Coenen, L.; Loorbach, D. The dynamics and opportunities of sustainability transitions in cities. In Urban Sustainability Transitions; Routledge: England, UK, 2017.

36. Tecnológico de Monterrey. Formula SAE. 2019. Available online: https://www.fsaeonline.com/ ... /gen/DownloadDocument.aspx (accessed on 28 October 2019).

37. Seward, D. Race Car Design; Metzler, J.B., Ed.; Springer: Berlin/Heidelberg, Germany, 2014.

38. Tecnológico de Monterrey. Reglamento de Campeonato 2016. 2019. Available online: https://www.electraton.com/wp-content/ uploads/2017/10/REGLAMENTO-2016.pdf (accessed on 1 October 2019).

39. MacPherson and Pseudo MacPherson Suspension. Available online: http://www.car-engineer.com/mac-pherson-and-pseudomac-pherson-suspension/ (accessed on 3 December 2019).

40. Double Wishbone Suspension. Available online: https://www.wikiwand.com/en/Double_wishbone_suspension (accessed on 3 December 2019).

41. Yin, R.K. Case Study Research, 4th ed.; Sage: Thousand Oaks, CA, USA, 2009. 